\title{
Peran layanan bimbingan dan konseling komprehensif dalam perencanaan karier pada siswa SMA
}

\author{
Serly Anggraini ${ }^{1^{*}}$, Mochammad Rifai $^{2}$, Abdul Muhid ${ }^{3}$ \\ UIN Sunan Ampel Surabaya ${ }^{1,3}$, MAN 4 Jombang $^{2}$ \\ *) Alamat korespondensi: Jl. Ahmad Yani No. 117, Surabaya, 602111, Indonesia; E-mail: serlyangg@gmail.com
}

Article History:

Received: 25/01/2021;

Revised: 21/06/2021;

Accepted: 27/06/2021;

Published: 30/06/2021.

How to cite:

Anggraini, S., Rifai, M., \& Muhid A. (2021). Peran layanan bimbingan dan konseling komprehensif dalam perencanaan karier pada siswa SMA. Teraputik: Jurnal Bimbingan dan Konseling, 5(1), pp. 16-23. DOI: 10.26539/teraputik. 51544

\begin{abstract}
Abstrak: Salah satu tugas perkembangan siswa SMA yaitu kesiapan untuk menata masa depan sebagai perannya menjadi dewasa. Oleh karena itu, dibutuhkan perencanaan karier yang matang agar siswa dapat merencanakan kariernya sesuai dengan kelebihan, kekurangan, kemampuan yang dimiliki oleh siswa. Bimbingan konseling sebagai unit integral sekolah bertujuan untuk memberikan bantuan maupun dukungan kepada siswa untuk mencapai tugas perkembangannya. Dengan adanya layanan bimbingan dan konseling komprehensif selaku upaya preventif agar siswa bisa mengambil keputusan dengan tepat dalam mencapai tugas perkembangannya baik perkembangan akademik, pribadi-sosial maupun karier. Terdapat empat komponen layanan bimbingan konseling dan komprehensif sesuai dengan perannya masingmasing yaitu layanan dasar, layanan penempatan dan perencanaan individual, dan layanan dukungan sistem. Penelitian ini bermaksud untuk menjabarkan tentang peran layanan bimbingan dan konseling komprehensif dalam perencanaan karier siswa SMA. Penelitian ini menggunakan studi literatur dengan mengkaji penelitian-penelitian terdahulu.
\end{abstract}

Kata Kunci: Bimbingan Konseling Komprehensif, Perencanaan Karier

Abstract: One of the development tasks of high school students is the readiness to organize the future as their role into adulthood. Therefore, careful career planning is needed so that students can plan their careers according to their strengths, weaknesses, and potentials. Counseling guidance as an integral part of the school aims to provide assistance and support to students to achieve their developmental tasks. With the existence of guidance and counseling services that are structured as a preventive effort so that students can make the right decisions in achieving their development tasks both in academic, personal-social and career development. There are four component services for guidance, counseling and services according to their respective roles, namely basic services, individual placement and planning services, and system support services. This study aims to describe the role of comprehensive guidance and counseling services in high school student career planning. This research uses literature study by examining previous studies.

Keywords: Comprehensive Guidance Counseling, Career Planning distributed under the Creative

License, which permits unrestricted use, distribution and reproduction in any medium provided the original work is properly cited. (C) 2021

Anggraini, S., Rifai, M., \& Muhid, A. (s)

\section{Pendahuluan}

Siswa SMA biasanya berusia 16-18 tahun dan sedang menghadapi perkembangan remaja, dimana masa remaja merupakan masa perpindahan antara masa anak-anak menuju dewasa. Dalam hal ini, tugas perkembangan remaja yaitu mengarah pada kesiapan untuk menata masa depan sebagai perannya menjadi dewasa (Kumara \& Lutfiyani, 2017). Sejalan dengan itu, Remaja mulai fokus dalam mengelola masa depan mereka (Hurlock, 1980). Terdapat beberapa hal perkembangan remaja dalam menyiapkan karier yaitu mengenali minat-bakat, kemampuan, dan nilai-nilai yang ingin dikejar serta mengenali bidang pekerjaan yang ingin dicapai dengan segala konsekuensi dan tujuannnya (Kumara \& Lutfiyani, 2017))

Untuk itu, siswa SMA yang akan melanjutkan pendidikan ke tahap yang lebih tinggi membutuhkan perencanaan karier yang baik sebelum mengambil keputusan dalam memilih program studi lanjutan agar dapat mencapai karier sesuai yang diinginkan. Akan tetapi, ada beberapa problem yang dialami oleh siswa ketika merencanakan karier, misalnya, siswa kurang memahami bagaimana memilih rencana studi yang selaras dengan kompetensi dan ketertarikannya, siswa kurang memahami lingkungan kerja, siswa masih bingung dengan pekerjaannya, dan siswa 
kurang mampu memilih pekerjaan, siswa cemas tentang apakah mereka ingin bekerja setelah lulus, siswa tidak memiliki pengalaman dalam memilih universitas tertentu atau melanjutkan pendidikan setelah lulus dari sekolah menengah, siswa tidak memahami karakteristik, ketentuan, kapasitas dan kapabilitas yang dibutuhkan untuk pekerjaan dan prospek karier (Supriatna \& Budiman, 2009).

Dalam menangani masalah tersebut, peran pendidikan sangatlah penting dalam mengembangkan potensi siswa sesuai dengan kompetensi yang dimiliki siswa serta membantu mengarahkan perkembangan siswa sesuai dengan kompetensi dan integrasi (Kartadinata, 2011). Sebab dalam proses perkembangannya, siswa memerlukan bimbingan karena kurangnya pemahaman tentang dirinya, lingkungan, dan pengalaman dalam menentukan masa depannya (Bhakti, 2015). Untuk itu, dibutuhkan layanan bimbingan agar siswa mampu menghadapi kesulitan dalam proses perkembangannya yang disebabkan ketidaktahuan dalam memahami pribadinya dan lingkungannya (Simamora \& Suwarjo, 2013). Layanan bimbingan konseling penting kehadirannya untuk menolong siswa dalam mengembangkan keahlian dirinya dan mencapai tugas perkembangannya (aspek fisik, sosial, emosi, intelektual, dan moral-spiritual) (Atmaja, 2014).

Untuk mewujudkan fungsi-fungsi layanan bimbingan dan konseling tersebut dibutuhkan bimbingan dan konseling yang berfokus pada perkembangan. Bimbingan dan konseling komprehensif adalah perspektif terbaru, dimulai dengan asumsi positif tentang potensi manusia (Suherman, 2011). Dalam hal ini, bimbingan konseling komprehensif mempunyai tanggung jawab untuk membantu siswa mencapai tingkat pengembangan diri dengan baik serta memberikan sarana prasarana agar siswa dapat meningkatkan kemampuan dalam memilih dan mengambil keputusan berdasarkan tanggung jawabnya sendiri. Selanjutnya, untuk membantu siswa memahami hubungan antara sekolah dan dunia kerja, merencanakan dan berhasil menyelesaikan kehidupan dari sekolah ke sekolah lanjutan dan/atau dunia kerja dan dari pekerjaan ke pekerjaan lain (American School Counselor Association, 2012). Oleh karena itu, pentingnya pendalaman karier oleh siswa guna mengetahui karekteristik pribadi dan lingkungannya diberbagai bidang karier dan budaya karier dimanapun berada (Purwanto, 2012). Dengan adanya pendalaman karier, diharapkan siswa memiliki banyak informasi tentang karier, pribadi, dan lingkungannya sehingga dapat menentukan perencanaan karier sesuai dengan potensi yang dimiliknya.

Perencanaan karier merupakan proses memahami peluang, keterbatasan, pilihan dan konsekuensi, menentukan tujuan terkait karier, dan merumuskan pekerjaan, pendidikan, dan rencana terkait (H. Simamora, 2011). Adapun siswa yang mampu merencanakan kariernya dengan baik saat di sekolah dapat bermanfaat untuk mengenali bakat-minat serta dapat mengambil keputusan yang tepat dalam karier yang akan dipilihnya. Perencanaan karier menjadi langkah awal bagi siswa untuk menggapai kesuksesannya di bidang karier. Siswa yang sukses dalam kariernya akan mendapatkan kepuasan tersendiri seperti rasa bangga memiliki pekerjaan yang diharapkan sedangkan siswa yang gagal dalam menempuh kariernya akan merasa rendah diri karena status penganggurannya. Menurut Donald E. Super pada teori perkembangan karier, di rentang usia 1524 tahun berada pada fase eksplorasi dimana remaja sudah mempunyai pilihan pekerjaan akan tetapi belum mampu mengambil keputusan (Hidayat et al., 2019). Keraguan dalam mengambil keputusan untuk memilih sekolah lanjutan dan memilih bidang pekerjaan yang sesuai dengan minat siswa dapat memberikan efek yang negatif sehingga menyebabkan kegagalan dalam kariernya. Agar siswa memperoleh kematangan dalam berkarier, siswa dapat memanfaatkan layanan bimbingan dan konseling di sekolah untuk membantunya dalam perencanaan karier.

Layanan bimbingan dan konseling komprehensif sebagai suatu preventif yang memungkinkan siswa untuk mengambil keputusan yang tepat ketika menyelesaikan tugas perkembangan mereka dalam perkembangan akademik, pribadi-sosial maupun karier. Metode bimbingan dan konseling perkembangan atau metode bimbingan dan konseling yang komprehensif berdasarkan pada perkembangan, pengembangan potensi dan upaya pemecahan masalah pada siswa (Myrick, 2011). Model ini, cocok digunakan untuk mengatasi berbagai macam persoalan yang dialami oleh siswa berdasarkan perkembangannya. Bimbingan komprehensif merupakan panangan mutakhir yang bertitik tolak dari premis positif tentang kemampuan yang dimiliki individu. Karena premis inilah, bimbingan dilihat menjadi suatu jalan untuk memfasilitasi perkembangan yang menitikberatkan pada upaya menolong siswa dalam semua fase perkembangannya termasuk dalam 
perkembangan karier siswa. Bimbingan konseling dan komprehensif mempunyai beberapa karakteristik seperti, memiliki cakupan layanan yang komprehensif, memiliki rencana yang berlandaskan pada nilai-nilai preventif, memiliki bentuk yang bersifat perkembangan, berpusat pada siswa, dilaksanakan secara kolaboratif, didukung oleh data, dan terintegrasi pada keseluruhan program sekolah (Hatch \& Bowers, 2002). Sehingga konselor/guru BK dituntuk untuk bisa membuat dan merencanakan program layanan yang dapat menampung semua kepentingan siswa. Tugas konselor tidak hanya berpusat pada pemecahan masalah, melainkan pencegahan serta pengembangan. Model ini memberikan mekanisme bagi konselor sekolah untuk merancang, mengkoordinir, melaksanakan, mengelola dan mengevaluasi program BK berdasarkan keberhasilan siswa. Di Indonesia, model bimbingan konseling dan komprehensif mengadaptasi dari model bimbingan dan konseling yang dikembangkan oleh ASCA. Akan tetapi, bimbingan komprehensif yang dikeluarkan ABKIN hanya memuat sistem pelayanannya saja. Diharapkan dengan adanya layanan bimbingan dan konseling komprehensif yang berdasarkan pada perkembangan siswa dapat membantu siswa keluar dari permasalahan yang dialaminya serta dapat membantu menyiapkan SDM yang bermutu dan meminimalisir kegagalan karier siswa untuk memilih studi lanjut maupun pekerjaan sesuai dengan kemampuan, minat dan bakat siswa.

Dari sudut pandang diatas, penulis ingin membahas peran layanan bimbingan dan konseling komprehensif dalam perencanaan karier pada siswa SMA.

\section{Metode}

Metode yang digunakan dalam penelitian ini adalah literatur review. Pencarian literatur nasional dan internasional dilakukan dengan sumber data yang diperoleh dari database Google Scholar, Directory of Open Access Journals (DOAJ), Research Gate, dan Portal Garuda Publikasi Indonesia Index (IPI). Dalam proses mencari literature yang sesuai dengan pembahasan, peneliti menggunakan kata kunci "Layanan Bimbingan dan Konseling Komprehensif", "Bimbingan Dan Konseling Komprehensif", dan "Perencanaan Karier Siswa SMA", dari pencarian tersebut literatur yang diperoleh dan bisa digunakan pada penelitian ini adalah literatur dari tahun 2008 sampai tahun 2019. Penulisan artikel ini, menitikberatkan pada perspektif perencanaan karier menurut Henry Simamora (2011) dengan judul Manajemen Sumber Daya Manusia dan perspektif bimbingan dan konseling komprehensif menurut ASCA dalam buku Hidayat (2019) dengan judul Karier: Teori Dan Aplikasinya Dalam Bimbingan Dan Konseling Komprehensif.

\section{Diskusi}

\section{Perencanaan Karier}

Perencanaan karier yaitu kegiatan siswa yang melibatkan pengambilan keputusan karier dimasa depan (Supriatna \& Budiman, 2009). Selain itu, individu dapat mengenali dan menyusun langkah-langkah untuk mecapai tujuan dalam karier yang ingin dicapai (H. Simamora, 2011). Adanya perencanaan karier bisa menolong siswa untuk memilih kariernya sesuai dengan potensi yang dimiliki, minat dan bakat serta peluang yang ada. Untuk itu, perencanaan karier penting dilakukan agar siswa tidak salah dalam memilih bidang karier yang dapat menyebabkan ketidakpuasan dan tidak merasa mencintai bidang kariernya. Sejalan dengan Pearson perencanaan karier adalah salah satu cara guna membantu siswa dalam memilih bidang karier yang sesuai dengan potensinya, sehingga dapat meraih kesuksesan yang cukup besar dalam pekerjaannya (Winkel \& Hastuti, 2006).

Adapun tujuan dilakukannya perencanaan karier yaitu untuk menentukan tujuan yang berhubungan dengan karier, menyadari peluang, kendala dan konsekuensi serta potensi yang melekat, menyiapkan rencana kerja atau pendidikan, dan maksud yang berhubungan dengan pengalaman pengembangan $(\mathrm{H}$. Simamora, 2011). Siswa merumuskan perencanaan kariernya sendiri dalam proses pemilhan karier. Sehingga, siswa harus memiliki beberapa informasi yang 
cukup mengenai karier, mengetahui apa yang harus dilakukannya setelah lulus sekolah, mengerti cara memasuki karier yang diinginkan, kendala apa jika ia memilih bidang tersebut, dan mengerti peluang dalam memasuki karier yang dipilinnya.

Menurut Jordan terdapat tiga aspek dalam perencanaan karier mencakup pengetahuan tentang karier, mencari informasi, perencanaan dan pengambilan keputusan (Yusuf, 2009). Berkaitan dengan hal tersebut, terdapat beberapa parameter antara lain mempelajari informasi pekerjaan, mendiskusikan pekerjaan dengan orang dewasa, menerima pendidikan tambahan (kursus), mengikuti kegiatan ekstrakurikuler, mengikuti pelatihan yang berkenaan dengan pekerjaan yang dibutuhkan, memahami kondisi kerja yang diperlukan, dan memahami pendidikan pekerjaan tersebut. Semoga dapat merencanakan karier setelah lulus nanti, mengetahui cara dan kesempaan memasuki karier, dan bisa mengatur waktu luang secara efektif (Suherman, 2009). Siswa yang mampu memenuhi indikator tersebut dapat melakukan perencanaan karier dengan baik, akan tetapi siswa yang tidak memenuhi indikator tersebut dapat dikatakan bahwa siswa tersebut kurang memiliki perencanaan yang kurang baik. Sehingga perlu adanya bimbingan atau bantuan kepada siswa agar dapat menyusun dan merencanakan karier yang ingin dicapainya setelah lulus dari sekolah menengah atas (SMA).

\section{Bimbingan dan Konseling Komprehensif}

Model bimbingan konseling komprehensif adalah model perkembangan dari ASCA (American school counselour association). Model tersebut bertujuan untuk menyelesaikan berbagai masalah konselor sekolah. Meskipun model telah dikembangkan untuk menangani masalah bimbingan dan konsultasi di Amerika Serikat, model ini dapat diadaptasi di Indonesia (Hidayat et al., 2019). Program bimbingan konseling komprehensif bersifat sistematis, artinya program dirancang untuk mencakup semua pihak, seperti siswa, keluarga, komunitas sekolah dan masyarakat (Purwaningrum, 2018). Selain siswa, partisipasi semua pihak tidak hanya menjadi penerima layanan tetapi juga sebagai mitra layanan. Adanya rencana ini menuntut pembimbing untuk merancang program yang mencakup kepentingan seluruh siswa dan merespon keberhasilan siswa akibat kerja guru bimbingan dan konseling.

Hal ini, memberikan peluang bagi ilmu bimbingan dan konseling untuk berubah menjadi lebih baik. Pasalnya, di Indonesia banyak terdapat masalah bimbingan dan konsultasi seputar pekerjaan administrasi, seperti pemeriksaan absensi siswa, pencatatan nilai siswa untuk pelanggaran, dan pemberian sanksi keterlambatan (Kumara \& Lutfiyani, 2017). Oleh karena itu, adaptasi model ini memberikan peluang kepada konselor untuk mendemonstrasikan kemampuan kerjanya, sehingga pekerjaan bimbingan dan konseling dapat dikenal dimasyarakat (Hidayat et al., 2019)

Terdapat empat komponen dalam model bimbingan konseling komprehensif yang meliputi, landasan berpikir (foundation), sistem layanan (delivery system), sistem manajemen (management system), dan akuntabilitas (accountability) (Hidayat et al., 2019). Namun, di Indonesia hanya mengadaptasi satu dari keempat komponen yaitu sistem layanannya saja (ABKIN, 2008). Seperti yang telah diatur permendikbud No. 111 tahun 2014 mengatur tentang bimbingan dan konseling pendidikan dasar dan menengah. Dalam pasal 6 ayat 1 komponen layanan bimbingan dan konseling mempunya empat prosedur yaitu layanan dasar, layanan penempatan dan perencanaan individual, layanan responsif, dan layanan dukungan sistem.

Layanan dasar adalah layanan yang diterima oleh siswa secara terstruktur dan terprogram serta terintegrasi sesuai dengan program sekolah terkait dengan pencapaian, kemampuan pribadi, sosial, belajar dan karier (Hatch \& Bowers, 2002). Selain itu, layanan dasar yaitu proses pemberian bantuan kepada seluruh konseli dengan menyiapkan pengalaman klasik dan terstruktur yang secara sistematis mengembangkan perilaku jangka panjang berdasarkan tugas pengembangannya (Depdiknas, 2007). Layanan ini bisa dilaksanakan melalui layanan orientasi, layanan informasi, bimbingan klasikal, bimbingann kelompok dan aplikasi instrumen (Hidayat et al., 2019).

Layanan penempatan dan perencanaan individual memiliki dua arti. Pertama, penempatan adalah program kurikuler yang ditujukan untuk pengembangan dan pendalaman yang berorientasi pada minat, bakat, kemampuan, dan berpusat pada siswa untuk beradaptasi dengan pilihan siswa, sedangkan perencanaan individual yakni untuk menolong siswa mengembangkan rencana yang 
berkenaan dengan masa depan. Dengan dasar memahami kelebihan dan kekurangan serta peluang di lingkungan (Depdiknas, 2007). Tujuannya adalah untuk membantu siswa mendesain, meninjau, dan mengatur pendidikan, karier, dan rencana pengembangan sosial pribadi mereka.

Layanan responsif merupakan proses pemberian bantuan kepada siswa yang membutuhkan bantuan dengan segera agar tidak mengalami hambatan dalam proses pencapaian tugas perkembangannya (Hidayat et al., 2019). Sedangkan dukungan sistem adalah pemberian layanan bantuan tidak langsung yang dapat melancarkan efektivitas dak efisiensi dalam proses layanan bimbingan dan konseling (Kumara \& Lutfiyani, 2017).

Bimbingan konseling komprehensif sendiri apabila diterapkan dengan baik dan tepat di setiap sekolah dapat memberikan kontribusi positif terhadap perkembangan akademik, pribadisosial, dan karier siswa di sekolah (Daryono et al., 2014). Menurut hasil penelitian Norman C Gysberg mengatakan ketika konselor sekolah menengah mempunyai waktu untuk mengembangkan struktur rencana bimbingan yang komprehensif dimana mereka bekerja, maka mereka akan memiliki perkembangan akademik, sosial pribadi dan karier yang positif (Gysbers \& Henderson, 2012). Berkontribusi pada pengembangan lingkungan belajar sekolah. Selain itu, konsultasi komprehensif juga dapat meningkatkan kualitas pendidikan. Dibuktikan dengan temuan yang menunjukkan bahwa konseling komprehensif dapat meningkatkan kualitas proses dan hasil pendidikan di SMA Jawa Barat (Nurihsan, 1998). Terdapat temuan juga bahwa bimbingan dan konseling yang komprehensif dapat meningkatkan kualitas pendidikan di SMA di Padang, Manado dan Nusa Tenggara Timur (Nurihsan, 2009).

\section{Layanan Bimbingan dan Konseling Komprehensif Dalam Perencanaan Karier Siswa di SMA}

Layanan bimbingan dan konseling dirancang untuk membantu konseli / siswa mencapai pengembangan pribadi, sosial, akademik dan karier terbaik serta kemandirian siswa. Sesuai fungsinya, bimbingan dan konsultasi ini dapat membantu mahasiswa memahami Individunya dan lingkungan sekitarnya (Hikmawati, 2010). Untuk itu diperlukan layanan bimbingan dan konseling untuk perkembangan siswa. Metode bimbingan dan konseling perkembangan atau bimbingan dan konseling komprehensif menitikberatkan pada bagaimana siswa mencapai tugas-tugas pengembangan mereka, pengembangan potensi, dan kemampuan pemecahan masalah siswa / konseli (Bhakti, 2015). Bimbingan dan konseling komprehensif mempunyai empat komponen sistem layanan sebagai upaya preventif dan komprehensif dalam menangani permasalahan siswa. Perencanaan karier dapat diimplementasikan didalam empat layanan pada bimbingan dan konseling komprehensif yang berdasarkan pada permendikbud no 111 tahun 2014 yakni layanan dasar, layanan perencanaan individual, layanan responsif, dan dukungan sistem (Kurniawan et al., 2019)

Pada layanan dasar dilakukan melalui bimbingan klasikal dengan memberikan materi tentang keterampilan pengambilan keputusan, pemantapan pemilihan studi, perkembangan dunia kerja, pemahaman konsep diri dan disampaikan melalui tatap muka dikelas atau bisa juga dengan leaflet, atau dengan metode menarik lainnya. Dalam layanan dasar terdapat layanan informasi sangat penting bagi siswa dalam mencari informasi tentang kariernya seperti informasi tentang jalur masuk di perguruan tinggi, informasi tentang beasiswa, dan pengetahuan tentang dunia kerja karena tidak semua lulusan akan melanjutkan ke sekolah lanjutan (Kulsum, 2013). Layanan informasi, studi lebih lanjut memiliki efek positif pada perencanaan karier, dan siswa yang melaksanakannya dapat merencanakan karier dengan baik (Hidayati, 2014). Aplikasi instrumental yang ada pada layanan ini berguna untuk mengumpulkan data kebutuhan siswa (need assesment) melalui aplikasi instrumen baik tes maupun non-tes, seperti Daftar Cek Masalah (DCM), Inventori Tugas Perkembangan (ITP), Alat Ungkap Masalah (AUM), Analisis Tugas Perkembangan (ATP) (Safitri \& Novirizka Hasan, 2018), selain itu bisa juga dari observasi maupun wawancara dan tes psikologi untuk mengetahui kebutuhan perencanaan karier siswa (Kumara \& Lutfiyani, 2017). Oleh karena itu, guru bimbingan dan konseling harus memiliki keterampilan dalam penggunaan asesmen tes maupun non tes (Riskiyah, 2017)

Layanan penempatan dan perencanaan individual merupakan elemen penting dalam perencanaan karier (Kumara \& Lutfiyani, 2017). Layanan bimbingan karier pada bimbingan dan 
konseling komprehensif termasuk didalam layanan penempatan dan perencanaan individu (Hidayat et al., 2019). Pada layanan penempatan kepada siswa SMA, bimbingan dan konseling memetakan siswa berdasarkan potensinya untuk ditempatkan dalam penjurusan IPA/IPS dengan bantuan biro psikologi. Sedangkan pada perencanaan individual, guru bimbingan dan konseing membantu mengarahkan siswa untuk memahami dirinya, kelebihan dan kelemahannya, potensinya dan kesempatan yang ada dalam merencanakan kariernya (Pangestuti, 2017). Proses ini bisa dilakukan dengan bimbingan konseling individual, konsultasi, dan bimbingan klasikal dengan memberikan informasi hasil asesmen dan implikasi dalam perencanaan karier kepada orang tua dan siswa, pemberian saran, membantu siswa dalam proses memasuki studi lanjut, dan lain sebagainya (Riskiyah, 2017). Guru bimbingan dan konseling dapat menggunakan media yang memuat tentang action plan untuk membantu siswa merencakanan kariernya (Lutfiyani et al., 2017).

Layanan responsif digunakan kepada siswa yang mempunyai problem tertentu yang dapat menghambat tugas perkembangan siswa. Dalam hal ini, guru dapat memberikan layanan konseling individu, konseling kelompok, konseling melalui media elektronik, mediasi, advokasi, dan kunjungan rumah sesuai dengan kebutuhan siswa. (Lutfiyani et al., 2017). Salah satu contohnya, dengan dilakukannya konseling kelompok dapat membantu meningkatkan perencanaan karier siswa. sejalan dengan temuan yang menyatakan adanya peningkatan yang signifikan sebelum dan sesudah dilakukannya konseling kelompok dalam perencanaan karier (Witriani \& Saam, 2015).

Layanan dukungan sistem ini dapat berupa kolaborasi dengan orang tua untuk mengetahui dukungan orang tua terhadap pemilihan studi lanjut, menjalin hubungan baik dengan perguruan tinggi, menjalin kerjasama dengan psikolog untuk mengetahui bakat dan minat siswa untuk melanjutkan studi lanjutan. Selain itu, konselor juga dapat berkolaborasi dengan personel yang ada di sekolah/diluar sekolah, pihak institusi lain untuk mendapatkan informasi dan feedback atas layanan yang diberikan kepada konseli (Purwaningrum, 2018). Guru bimbingan dan konseling juga dapat mengikuti seminar, menghadiri MGBK (Musyawarah Guru Bimbingan dan Konseling), menghadiri pelatihan-pelatihan untuk meningkatkan pengetahuannya dalam keilmuan bimbingan dan konseling yang nantinya berguna untuk kelancaran pelayanan bimbingan dan konseling di sekolah.

\section{Simpulan}

Pada masa SMA, individu mulai memikirkan dan menata masa depan yang ingin dicapai. Akan tetapi, sebagian besar siswa mempunyai masalah dalam merencanakan kariernya. Perencanaan karier sangatlah penting bagi setiap individu untuk membantu memilih kariernya sesuai dengan potensi yang dimiliki, minat dan bakat serta peluang yang ada. Untuk itu, perencanaan karier penting dilakukan agar siswa tidak salah dalam memilih bidang karier yang dapat menyebabkan ketidakpuasan dan tidak merasa mencintai bidang kariernya. Dalam hal ini keberadaan layanan bimbingan dan konseling sangat penting untuk membantu siswa menyadari potensinya dan menyelesaikan tugas-tugas perkembangannya (fisik, sosial, emosional, intelektual, dan moral). Layanan bimbingan dan konseling yang komprehensif adalah pekerjaan preventif yang memungkinkan siswa untuk membuat keputusan yang tepat ketika menyelesaikan tugas perkembangan mereka dalam perkembangan akademik, sosial-pribadi dan karier.

Terdapat empat komponen layanan bimbingan dan konseling komprehensif dalam perencanaan karier siswa yaitu 1) layanan dasar dilakukan melalui bimbingan klasikal, layanan informasi, dan need assesment melalui aplikasi instrumental untuk membantu memudahkan dalam merencanakan karier siswa. 2) Layanan penempatan dan perencanaan individual berguna untuk membantu mengarahkan siswa untuk memahami dirinya, kelebihan dan kelemahannya, potensinya dan kesempatan yang ada dalam merencanakan kariernya. 3) Layanan responsif digunakan kepada siswa yang memiliki masalah tertentu yang dapat menghambat tugas perkembangan siswa. dapat dilakukan dengan memberikan layanan berupa konseling individual, konseling kelompok, konseling melalui media elektronik, konsultasi, mediasi, advokasi dan kunjungan rumah sesuai dengan kebutuhan siswa. 4) Layanan dukungan sistem ini dapat berupa kolaborasi dengan orang 
tua untuk mengetahui dukungan orang tua terhadap pemilihan studi lanjut, menjalin hubungan baik dengan perguruan tinggi, menjalin kerjasama dengan psikolog untuk mengetahui bakat dan minat siswa untuk melanjutkan studi lanjutan.

Pembahasan dalam penelitian ini masih jauh dari kata sempurna. Oleh sebab itu, disarankan bagi peneliti selanjutnya untuk memperdalam kajian teori tentang layanan bimbingan dan konseling komprehensif yang dilakukan di SMA untuk menunjang perencanaan karier siswa di SMA. Diharapkan juga, untuk guru bimbingan dan konseling dapat memberikan inovasi terbaru dalam setiap pelayanan yang diberikan agar siswa dapat berkembang sesuai dengan potensinya. .

\section{Ucapan Terima Kasih}

Pada bagian ini, Saya ingin mengucapkan terimakasih kepada Dosen mata kuliah bimbingan dan Konseling sekolah yang tidak henti-hentinya memberikan bimbingan dan arahan dalam penulisan jurnal ini. Tak lupa juga saya ucapkan terimakasih kepada guru bimbingan dan konseling yang memberikan arahan dalam penulisan jurnal ini. Selanjutnya, terimakasih saya ucapkan kepada orang tua saya yang memberikan semangat, mengingatkan makan, memberikan kuota, agar saya bisa menyelesaikan rangkaian jurnal ini. Sekali lagi, saya ucapkan terimakasih kepada semua teman-teman yang tidak bisa saya sebutkan satu persatu yang telah memberikan dukungan dan semangat agar dapat menyelesaikan penulisan dengan baik.

\section{Daftar Rujukan}

ABKIN. (2008). Penataan Pendidikan Profesional Konselor DAN Layanan Dalam Jalur Pendidikan Formal. Depdiknas.

American School Counselor Association. (2012). ASCA national model: A framework for school counseling programs. American School Counselor Association.

Atmaja, T. T. (2014). Upaya Meningkatkan Perencanaan Karier Siswa Melalui Bimbingan Karier dengan Penggunaan Media Modul. PSIKOPEDAGOGIA Jurnal Bimbingan Dan Konseling, 3(2), 57. https://doi.org/10.12928/psikopedagogia.v3i2.4466

Bhakti, C. P. (2015). Bimbingan Dan Konseling Komprehensif : Jurnal Fokus Konseling, 1(2), 93106.

Daryono, Sugiharto, \& Sutoyo, A. (2014). Model Program Bimbingan dan Konseling Komprehensif di Taman Kanak-kanak. Jurnal Bimbingan Konseling, 3(2), 159-166. http://journal.unnes.ac.id/sju/index.php/jubk

Depdiknas. (2007). Rambu-Rambu pelaksanaan BK dalam Jalur Pendidikan Formal. Ditjen PMPTK.

Gysbers, N. C., \& Henderson, P. (2012). Developing and Managing Your School Guidance and Counseling Program Fourth Edition. American Counseling Assosiation.

Hatch, T., \& Bowers, J. (2002). The Block to Build On. ASCA School Counselor.

Hidayat, D. R., Cahyawulan, W., \& Alfan, R. (2019). Karier: Teori dan Aplikasi dalam Bimbingan dan Konseling Komprehensif. In E-BOOK. Jejak Publisher. https://books.google.co.id/books?id=6i_SDwAAQBAJ\&printsec=frontcover\&dq=Karier:+Teori+ dan+Aplikasi+dalam+Bimbingan+dan+Konseling+Komprehensif.\&hl=en\&sa=X\&ved=2ahUKE wjMiJi5mqfuAhXh73MBHU4ZAw4Q6AEwAHoECAEQAg\#v=onepage\&q=Karier\%3A Teori dan Aplikasi dalam $\mathrm{Bi}$

Hidayati, N. W. (2014). Pengaruh Layanan Informasi Studi Lanjut Terhadap Perencanaan Karier Siswa. Jurnal Edukasi, 1(1), 94-101.

Hikmawati, F. (2010). Bimbingan Konseling. PT. Rajawali Grafindo Persada.

Hurlock, B. E. (1980). Psikologi Perkembangan. Penerbit Erlangga.

Kartadinata, S. (2011). Menguak Tabir Bimbingan Dan Konseling Sebagai Upaya Pedagogis. In UPI.

Kulsum, S. (2013). Peranan Bimbingan dan Konseling dalam Domain Pengembangan Diri Siswa 1. Jurnal Konseling Dan Pendidikan, 1(1), 67. https://doi.org/10.29210/11200 
Kumara, A. R., \& Lutfiyani, V. (2017). Strategi Bimbingan Dan Konseling Komprehensif Dalam Perencanaan Karier Siswa Smp. G-COUNS Jurnal Bimbingan Dan Konseling, 1(2), 180-191.

Kurniawan, S. J., Kumara, A. R., \& Bhakti, C. P. (2019). Strategi Layanan Perencanaan Individual untuk Mengembangkan Work Readiness pada Siswa SMK. Seminar Nasional Pendidikan (Sendika), 3(November), 109-116.

Lutfiyani, V., Bhakti, P., \& Dahlan. (2017). Strategi Layanan Bimbingan dan Konseling Komprehensif dalam Pengembangan Self-Knowledge pada Siswa Sekolah Dasar. SENDIKA: Seminar Nasional Pendidikan FKIP UAD, I(20), 370-377. http://eprints.uad.ac.id/8589/1/14. Vivi Lutfiyani.\%2CS.Pd.pdf

Myrick, R. D. (2011). Developmental Guidance and Counseling: A Practical Approach Fifth edition. Educational Media Corporation.

Nurihsan, J. (1998). Bimbingan Komprehensif: Model Bimbingan dan konseling di Sekolah Menengah Umum (Studi Pencarian Model Bimbingan untuk Meningkatkan Mutu dan Sistem Manajemen Layanan Bimbingan di Beberapa SMU Negeri Jawa Barat). In Disertasi.

Nurihsan, J. (2009). Model konseling Multibudaya Dalam Kerangka Bimbingan Komprehensif untuk Mengembangkan Kompetensi Sosial Siswa Usia Remaja Kearah Persatuan Nasional Indonesia. Laporan Hibah Strategis Nasional.

Pangestuti, R. W. (2017). Strategi Layanan Perencanaan Individual. Prosiding Seminar Nasional Peran Bimbingan Dan Konseling Dalam Penguatan Pendidikan KarakterKonseling Dalam Penguatan Pendidikan Karakter, 159-172.

Purwaningrum, R. (2018). Bimbingan dan Konseling Komprehensif sebagai Pelayanan Prima Konselor ( Ribut Purwaningrum). Jurnal IImiah Konseling, BK FKIP UTP, 18(1), 18-27.

Purwanto, E. (2012). Peran Kecerdasan Emosional dan Eksplorasi Anak. PSIKOPEDAGOGIA Jurnal Bimbingan Dan Konseling, 1(1), 7-13.

Riskiyah, R. (2017). Implementasi Permendikbud No. 111 Tahun 2014 dan Implikasinya terhadap Kompetensi dan Uraian Tugas Guru Bimbingan Konseling. Jurnal Pendidikan (Teori Dan Praktik), 2(1), 44. https://doi.org/10.26740/jp.v2n1.p44-55

Safitri, N. E., \& Novirizka Hasan, S. U. (2018). Strategi Layanan Bimbingan Dan Konseling Dalam Pengembangan Nilai Karakter Religius. JURKAM: Jurnal Konseling Andi Matappa, 2(1), 19. https://doi.org/10.31100/jurkam.v2i1.64

Simamora, A. L., \& Suwarjo. (2013). Manajemen Bimbingan Dan Konseling Di SMAN 4 Yogyakarta. Jurnal Akuntabilitas Manajemen Pendidikan, 2(3), 44-57.

Simamora, H. (2011). Manajemen Sumber Daya Manusia. YKPN.

Suherman, U. (2009). Konseling Karier Sepanjang Rentang Kehidupan. UPI.

Suherman, U. (2011). Pembangun Karakter dan Budaya Bangsa Melalui Bimbingan Komprehensif Berbasis Nilai Alquran (Tinjauan Filosofis tentang Hakikat dan Peran Manusia). Pidato Pengukuhan Jabatan Guru Besar.

Supriatna, M., \& Budiman, N. (2009). Bimbingan Karier di SMK. In Dalam e-book.

Winkel, W. ., \& Hastuti. (2006). Bimbingan dan Konseling di Institut Pendidikan. Media Abadi.

Witriani, R., \& Saam, Z. (2015). Pengaruh Layanan Bimbingan Kelompok Terhadap Perencanaan Karier Siswa Dalam Memasuki Perguruan Tinggi Kelas X Sma Negeri 2 Pekanbaru Tahun Pelajaran 2014 / 2015. 1-10.

Yusuf, S. (2009). Program Bimbingan Dan Konseling Di Sekolah. Rizqi Press.

\section{Competing interests:}

The authors declare that they have no significant competing financial, professional or personal interests that might have influenced the performance or presentation of the work described in this manuscript. 